УДК 658: 004. 4

DOI: https://doi.org/10.37320/2415-3583/18.10

Чернікова Н.М.

кандидат економічних наук, доцент

Полтавська державна аграрна академія

ORCID: https://orcid.org/0000-0002-0079-6411

\title{
АНАЛІЗ ПРОГРАМНИХ РІШЕНЬ З АВТОМАТИЗАЦІЇ БІЗНЕС-ПРОЦЕСІВ ПІДПРИЕМСТВ
}

Статтю присвячено аналізу програмних рімень для автоматизачії бізнес-прочесів та рівня їх застосування вітчизняними підприємствами. Даний аналіз підтвердив, щяо кожне програмне рімення має свою галузь застосування, а також переваги та недоліки. Вивчено досвід застосування окремих програмних продуктів на підприємствах. Проведено групування програмних рішень за різними класифікаційними ознаками. Установлено провідні компанії, які пропонують послуги з розроблення, впровадження та технічного супроводу даних програм, а також їхні конкурентні переваги. Запропоновано підходи до вибору того чи іншого технологічного рішення для окремих підприємств. Доведено необхідність автоматизаиії якомога більиої кількості бізнес-проиесів підприємств та визначено існуючі можливості для втілення иьього заходу.

Ключові слова: програмні продукти, бізнес-прочеси, автоматизачія, аналіз та групування програмних рішень, можливості впровадження, конкурентні переваги.

Постановка проблеми. Питання актуальності та необхідності автоматизації бізнес-процесів у сучасних умовах господарювання $є$ очевидним. Її роль ще більше посилюється в умовах мінливого ринку та підвищеної конкуренції. Звичайно, будь-яке програмне рішення та його впровадження - це інвестиція для підприємства, тому завжди виникають сумніви щодо доцільності, ефективності та надійності тих чи інших автоматизованих систем. Також чимало суперечок виникає з приводу можливої оптимізації або повної зміни організаційної, виробничої, збутової, управлінської та інших структур підприємства, а також перепідготовки кадрів та залучення додаткового персоналу, спричинених підвищенням рівня автоматизації виробництва.

Проте вигоди від упровадження автоматизованих систем у діяльність підприємств очевидні, це: отримання достовірнішої інформації шляхом мінімізації людського фактору; економія ресурсів завдяки оптимізації бізнес-процесів; підвищення ефективності управління шляхом досягнення найвищої оперативності прийняття рішень та ін. Тому питання постає тільки у виборі такого програмного рішення для автоматизації бізнес-процесів, яке максимально відповідатиме запитам власників бізнесу та саме бізнесу.

Аналіз останніх досліджень і публікацій. Питанням автоматизації бізнес-процесів підприємств приділено увагу в працях таких вітчизняних науковців, як А.П. Ладанюк, І.В. Ельперін, Т.Л. Мостенська, А.В. Гандурський, Д.М. Одарченко, Н.С. Орлова, К.М. Сокол, К.І. Дмитрів [1-8], але у цьому напрямі ще недостатньо напрацювань. Сьогодні інформація про наявні системи автоматизації бізнесу, їх характеристики, функціональні можливості, переваги, недоліки та ефективність впровадження $є$ прерогативою авторів інформаційних блогів, розробників даних програмних рішень, а також учених та фахівців переважно технічних галузей. У зв'язку з активізацією цифрових перетворень у країні та низькою вивченістю даного питання виникає необхідність його детальнішого розгляду та систематизації.
Мета статті полягає в аналізі програмних рішень 3 автоматизації бізнес-процесів та їх групуванні за різними ознаками для подальшого застосування в практичній діяльності підприємств.

Виклад основного матеріалу. У перекладі з англійської бізнес-процес - це будь-яка діяльність, що має вхідний продукт, додає вартість до нього та забезпечує вихідний продукт для внутрішнього та зовнішнього споживача. Існує три види бізнес-процесів: процеси управління, основні та обслуговуючі процеси. Відповідно, й програмні продукти, які створюються для їх автоматизації, створюються з урахуванням такого поділу. Одними 3 перших почали автоматизуватися обслуговуючі бізнеспроцеси, а саме облікові. Цей досвід показав, наскільки автоматизація полегшує та пришвидшує виконання в даному разі облікових процесів, скорочення витрат ручної праці. Проте попри всі плюси такі зміни призвели до скорочення штату бухгалтерів та підвищення рівня безробіття, до появи таких проблем, як старіння знань, умінь та кваліфікацій працівників. Але процес автоматизації вже давно запущений, він довів свою перевагу перед низькотехнологічними аналогами.

Розглянемо, які сьогодні існують системи автоматизації бізнес-процесів та які IT-компанії пропонують послуги 3 їх розроблення, впровадження, налаштування та технічної підтримки. Майже всі ці компанії вважають головною перевагою автоматизації бізнеспроцесів звільнення часу для реалізації стратегічних цілей замість виконання рутинних операцій.

Найпопулярнішими серед таких систем є CRM-, ERP-, WMS-, TSM-, ВРМ-системи та ін. Усі вони є системами керування базами даних, але кожна 3 них має свої різновиди, які можуть існувати самостійно або бути складовою частиною комплексного продукту. Такі системи відрізняються одна від одної функціональними можливостями, вартістю, складністю налаштування, набором додаткових послуг із навчання та технічної підтримки тощо.

CRM у перекладі 3 англійської означає «управління відносинами $з$ клієнтом» (Customer Relationship 
Management). Дане програмне рішення спрямоване на автоматизацію роботи з потенційними та існуючими клієнтами, полегшення та оптимізацію роботи відділу продажів. Вони, як і будь-яке програмне забезпечення, можуть бути власного розроблення або готовим ліцензійним рішенням, адаптованим під особливості діяльності підприємства.

Основними перевагами CRM-систем є:

- поліпшення взаємодії з клієнтами;

- збереження інформації про клієнта;

- хронологія контактування з ним;

- налаштування SMS-нагадування про статус замовлення та/або зустріч;

- формування поточних документів та звітів за заданим шаблоном;

- розраховує вартість угод;

- зберігає історію здійснення покупок.

Усі ці переваги дають змогу зекономити час, зменшити кількість помилок і, відповідно, підвищити продуктивність праці, зменшити витрачання ресурсів, поліпшити ефективність управління та фінансово-економічні показники.

Перші CRM-системи почали з'являтися ще в 70-ті роки минулого століття, але класифікували їх за певними критеріями тільки у 2009 р., коли компанія Gartner провела перший Customer Relationship Managment Summit. Сьогодні CRM-системи мають такі види: операційні (діють під час безпосереднього контакту з клієнтом); аналітичні (полегшують аналіз даних); колабораційні (забезпечують спрощення спілкування $з$ клієнтом); комбінаційні (поєднують дві та більше функцій). Найбільшої популярності серед них набувають комбіновані, які дадуть змогу в умовах конкуренції, що зростає, створити для підприємств продукт, який максимально задовольнятиме його потреби.

ERP - це також абревіатура від англійської Enterprise Resource Planning, що розшифровується як «планування ресурсів підприємства». ЕRP-системи - це великий та складний сучасний продукт, створений для автоматизації бізнес-процесів, пов'язаних 3 управлінням фінансовими, трудовими та виробничими ресурсами підприємства, їх плануванням, обліком та контролем на всіх етапах виробничого циклу - від постачання ресурсів до реалізації готової продукції. На відміну вид CRM-систем вони оперують конкретними даними, які відображують окремі процеси або їх сукупність із подальшим аналізом цих даних [10].

ERP-системи можна поділити: за призначенням - на галузеві та системи загального призначення; за типом організації - на публічні, приватні та змішані; за архітектурою системи - $з$ єдиною архітектурою та модульними системами; за ліцензією - з відкритим або закритим кодом. Модульні системи мають переваги завдяки можливості впроваджувати продукт поступово та комбінувати окремі модулі. I зазвичай вони із закритим кодом. Перевагами ERP-систем є:

- простота у використанні та інтеграція всіх функцій;

- прозорі наскрізні бізнес-процеси;

- економія часу та ресурсів;

- ефективність та швидкість прийняття управлінських рішень;

- поліпшення якості сервісу з мінімізацією витрат;

- збільшення прибутків;
- підвищення рівня інформаційної безпеки.

Головним недоліком та ризиком під час упровадження даних систем є велика вартість придбання та підтримки їх у робочому стані тривалі строки впровадження.

За даними Allied Market Research (AMR), світовий ринок ERP-систем щорічно зростає на 7,2\% та до 2020 р. досяг 41,69 млрд дол. США. За кордоном найбільш популярними $є$ ЕRР-системи американської компанії Oracle. На другому місці - німецька компанія SAP [3]. Далі зі значним відставанням ідуть Sage, Epicor, Infor, Microsoft та інші розробники. Середній період окупності впроваджених систем, за даними експертів, становить три роки, а поліпшення показників діяльності компаній коливається від 40\% до 80\% [9].

Незважаючи на достатньо високий рівень автоматизації багатьох процесів у сучасних умовах, однією 3 найбільших статей витрат усе ще залишаються витрати на оплату праці. За даними Forrester Research, на їхню частку у США припадає майже 36,4\%. HRMсистеми (Human Resource Management) - комплексні автоматизовані системи управління персоналом. Вони створюються 3 метою залучення та утримання цінних для підприємства спеціалістів і відрізняються від традиційних систем автоматизації кадрового обліку та розрахунку заробітної плати розширеною функціональністю. Зокрема, до таких функцій, як кадровий облік, штатний розклад, документообіг, облік робочого часу та відпусток, пенсійний та військовий облік, заробітна плата, податки, відрахування та ін. додаються ще функції для роботи з якісними показниками персоналу. Такі функції управління персоналом прийшли із західної практики, і до них можна віднести:

- оцінку персоналу, його компетенцій;

- аналіз ефективності персоналу та управління кар'єрою;

- мотивацію персоналу;

- управління навчанням (підвищення кваліфікації) відповідно до цілей компанії;

- планування потреби в персоналі та формування кадрового резерву.

Таким чином, автоматизовані системи управління персоналом допомагають упорядкувати облікові та розрахункові процеси, пов'язані з персоналом, та знизити втрати від руху людських ресурсів. За даними American Management Association, утрати від зміни співробітника можуть досягати від 30\% до 150\% його річного окладу залежно від рівня його знань та навичок, що, своєю чергою, відбиватиметь на ефективності діяльності підприємства у цілому [11].

Одними із найдавніших автоматизованих систем $\epsilon$ WMS-системи (Warehouse Management System) - системи управління складом, які може використовувати будь-яке виробниче підприємство, логістичні відділи тощо. Сьогодні ці програмні продукти містять складні комплекси 3 робототехнікою, голосовим керуванням та ін. Використання даних систем дає змогу підприємствам підвищити ефективність управління бізнес-процесами на складі, контроль їх виконання, оптимізувати кількість працівників складу та підвищити їх продуктивність, синхронізувати складські операції з обліковими процесами та формувати звіти, у результаті чого поліпшуються показники ефективності використання 
та оборотності запасів, а також якість обслуговування клієнтів. Складність такої системи залежить від розміру складу, який вона обслуговуватиме. Вони сьогодні $\epsilon$ найбільш популярними серед вітчизняних та іноземних розробників.

TSM-системи (Time Slot Management System) логістичні рішення з управління часовими інтервалами постачання, які допомагають планувати постачання автотранспортом, оптимізувати діяльність працівників складу та завантажувальних площадок. Перевагами їх використання є скорочення часу простоїв, скоординованість дій усіх учасників цього процесу, прозорість і база для аналізу, контроль завантажувальних та розвантажувальних процесів та ресурсів. На відміну від ERP- та WMS-систем дана система надає можливість контролювати часовий інтервал - від прибуття товару на склад до його відвантаження.

Для закріплення за кожним бізнес-процесом відповідальної особи-виконавця існують так звані ВРМсистеми (Business Process Management - управління бізнес-процесами). Вони полегшують роботу керівництва, здійснюючи в автоматичному режимі комплексне управління персоналом, виробництвом, і сприяють підвищенню ефективності підприємства у цілому. Головне, що відрізняє дані системи від ЕRP-систем, це впорядкування послідовності дій працівників різних структурних підрозділів, контроль повноти та своєчасності їх виконання та підвищення ефективності управління.

У сфері планування фінансових ресурсів існують FRP-системи (Finance Requirements Planning), але вони не дуже розповсюджені, тому що всі ERP-системи містять у собі модуль з управління фінансовими потоками.

Також існують системи електронного документообігу - EDMS- та ECM-системи, але їх використання обмежується автоматизацією руху документів на підприємстві, а саме їх реєстрацією, погодженням, підписанням, ознайомленням. Дані системи на відміну від ERP-систем не пов'язують документообіг 3 іншими процесами на підприємстві. Розрізняють індивідуально розроблені, універсальні та комбіновані системи управління електронним документообігом.

Дані системи, їх характеристика, сфери застосування, а також пропозиції на ринку IT-технологій представлено в таблиці.

У результаті проведених досліджень існуючих в Україні систем автоматизації бізнес-процесів підприємств їх було згруповано за певними класифікаційними ознаками:

- за ступенем охоплення бізнес-процесів: спеціалізовані, універсальні та змішані. Спеціалізовані програмні рішення, як правило, створюються для різних галузей $з$ урахуванням їхньої специфіки та унікальності діяльності. Іноді галузеві рішення розробляються на базі універсальних. Наприклад, система «Управління будівельною організацією/сільськогосподарським підприємством для України» була розроблена на базі «Управління виробничим підприємством для України» тощо;

- за розробниками: власного розроблення та стандартні ліцензійні рішення. Кожне із цих видів рішень для автоматизації бізнес-процесів має певні позитивні боки й недоліки. Так, програмні рішення власного роз- роблення створюються 3 урахуванням особливостей діяльності підприємства, витрати на їх розроблення, впровадження та обслуговування будуть нижче, ніж у разі замовлення спеціалізованого ліцензійного рішення. Але витрати на тестування та вдосконалення такого програмного забезпечення можуть значно підвищити його вартість для підприємства. Недоліки розроблення власних IT-рішень будуть перевагами для стандартних ліцензійних рішень, та навпаки;

- за функціональністю: однофункціональні та багатофункціональні. Однофункціональні системи автоматизації спрямовані на автоматизацію окремих бізнеспроцесів та виконання конкретних функцій. Прикладом може бути створення ботів як досвідченого помічника для спрощення комунікації з клієнтами, використання GPS-навігації у землеробстві для поліпшення функцій контролю, запровадження програми автоматизації годівлі тварин ProFeed та ін. Але сьогодні переважна більшість програмних рішень багатофункціональна та спрямована на вирішення одразу декількох завдань;

- за країною походження: вітчизняні та закордонні. Тут слід розрізняти системи, які повністю створюються в Україні або в інших країнах, починаючи від ідеї, їі розроблення, власне створення IT-продукту, його реалізації та впровадження до технічної підтримки та вдосконалення. Проте, як зазначалося вище, сьогодні вітчизняні компанії здійснюють сервісні послуги з реалізації ідей закордонних розробників та їх адаптації до вітчизняних умов господарювання;

- за кількістю вміщуваних модулів: прості та складні. Наприклад, більшість ЕRР-систем уміщує, як правило, декілька модулів, таких як логістичний, виробничий, маркетинговий, збутовий, модуль 3 управління персоналом та ін. Водночас інші системи, наведені в табл. 1, по відношенню до ERP можна вважати простими;

- за сферою застосування: виробничі, обслуговуючі, комплексні. Усі вони засновані на використанні програмного забезпечення у виробництві та/або його обслуговуванні. Завданнями автоматизації у цьому разі $\epsilon$ підвищення якості виконання операцій, скорочення часу для їх здійснення, зниження витрат, а також підвищення стабільності і точності їх виконання;

- за галузевою ознакою: промислові, аграрні, торговельні, будівельні та ін. Розробляються відповідно до особливостей ведення галузі з урахуванням іiі специфіки.

У кожного підприємства $є$ потреби, які можуть бути спільними або відмінними, тому й підходи у виборі систем автоматизації бізнес-процесів різнитимуться, а їх класифікація дасть змогу спростити вибір необхідного програмного рішення відповідно до потреб замовника.

Розробленням програмного забезпечення 3 автоматизації бізнес-процесів займаються сьогодні IT-компанії по всьому світу, серед яких перші місця займають SAP, Oracle, Microsoft, Epicor. Але останніми роками простежується прогрес і серед вітчизняних компаній. Лідерами українських IT-корпорацій є EPAM, SoftServe, GlobalLogic, Luxoft, Ciklum, але фактично, як уже зазначалося, усі вони надають сервісні послуги з розроблення IT-рішень, є виробниками замовного програмного забезпечення, вітчизняними 
Таблиця 1 - Комплексний аналіз програмних рішень 3 автоматизації бізнес-процесів підприємств

\begin{tabular}{|c|c|c|c|}
\hline Вид системи & Сфера застосування & Унікальність продукту & $\begin{array}{c}\text { Вітчизняні } \\
\text { та закордонні розробники }\end{array}$ \\
\hline ERP-системи & $\begin{array}{l}\text { комплексна автоматизація } \\
\text { бізнес-процесів } \\
\text { підприємств }\end{array}$ & $\begin{array}{l}\text { управління фінансовими, трудовими та } \\
\text { виробничими ресурсами підприємства, } \\
\text { їх планування, облік та контроль на всіх } \\
\text { етапах виробничого циклу - від постачання } \\
\text { ресурсів до реалізації готової продукції }\end{array}$ & $\begin{array}{l}\text { Фінексперт } \\
\text { IT-Enterprise } \\
\text { Мегаполіс } \\
\text { Bob’s World AG } \\
\text { ORACLE } \\
\text { SAP AG } \\
\text { SAGE } \\
\text { EPICOR } \\
\text { INFOR } \\
\text { MICROSOFT }\end{array}$ \\
\hline CRM-системи & $\begin{array}{l}\text { автоматизація управління } \\
\text { відносинами з клієнтом }\end{array}$ & $\begin{array}{l}\text { автоматизація роботи з потенційними } \\
\text { та існуючими клієнтами, полегшення } \\
\text { та оптимізація роботи відділу продажів }\end{array}$ & \begin{tabular}{|l|} 
БITРIКС24 \\
INFORM CASCADE \\
ACT, GoldMine, Sales Expert, \\
Clientele, Парус-Клієнт, Конс- \\
Маркетинг \\
ВАAN, Siebel, Oracle, SAP \\
\end{tabular} \\
\hline HRM-системи & $\begin{array}{l}\text { автоматизація управління } \\
\text { персоналом }\end{array}$ & $\begin{array}{l}\text { автоматизує процеси, пов'язані не лише } \\
\text { з кількісними показниками, а й із якісними }\end{array}$ & $\begin{array}{l}\text { ADP } \\
\text { CERIDAN } \\
\text { KRONOS } \\
\text { SAGE NORTH AMERICA } \\
\text { MANGROVE }\end{array}$ \\
\hline WMS-системи & $\begin{array}{l}\text { автоматизація управління } \\
\text { складом }\end{array}$ & $\begin{array}{l}\text { оптимізація та раціоналізація складської } \\
\text { праці, покращення обліку та контролю } \\
\text { запасів та готової продукції }\end{array}$ & $\begin{array}{l}\text { SAP IBP } \\
\text { BENOY }\end{array}$ \\
\hline TSM-системи & $\begin{array}{l}\text { автоматизація управління } \\
\text { транспортною логістикою }\end{array}$ & $\begin{array}{l}\text { упорядкування завантажувальних } \\
\text { та розвантажувальних процесів, } \\
\text { управління часом }\end{array}$ & RELOG \\
\hline ВРМ-системи & $\begin{array}{l}\text { автоматизація } \\
\text { управлінських процесів }\end{array}$ & $\begin{array}{l}\text { управління послідовністю та збалансованість } \\
\text { дій працівників різних структурних } \\
\text { підрозділів }\end{array}$ & $\begin{array}{l}\text { ELMA BPN } \\
\text { STUDIO CREATIO } \\
\text { DOCVISION } \\
\text { COMINDWARE BUSINESS } \\
\text { APPLICATION } \\
\end{array}$ \\
\hline FRP-системи & \begin{tabular}{|l} 
автоматизація управління \\
та контролю фінансових \\
потоків підприємства \\
\end{tabular} & $\begin{array}{l}\text { прогнозування, планування, аналіз } \\
\text { та контроль грошових потоків підприємства }\end{array}$ & FINANCE CONTROLLING \\
\hline $\begin{array}{l}\text { EDMS-, } \\
\text { ЕСМ-системи }\end{array}$ & $\begin{array}{l}\text { автоматизація руху } \\
\text { документів на } \\
\text { підприємстві }\end{array}$ & $\begin{array}{l}\text { поліпшення системи зберігання, пошуку } \\
\text { документів, оперативності виконання }\end{array}$ & $\begin{array}{l}\text { IBM LOTUS-NOTES } \\
\text { MICROSOFT SHAREPOINT } \\
\text { DocsVision } \\
\text { Optima - Workflow BAS } \\
\text { Документообіг КOPП } \\
\text { M.E.Doc } \\
\text { Megapolis } \\
\text { FossDoc }\end{array}$ \\
\hline
\end{tabular}

Джерело: проаналізовано та згруповано автором на підставі вивчення ринкових пропозицій

підрозділами американських, швейцарських та британських компаній. Проте це не заважає активному впровадженню українських IT-розробок у діяльність підприємств різних сфер і галузей, які мають власну мережу в одному або кількох містах України, різні фінансові можливості та стимули щодо втілення автоматизованих систем управління бізнес-процесами.

Висновки. Аналіз програмних рішень 3 автоматизації бізнес-процесів, їхніх функціональних можливостей, переваг та недоліків застосування, досвід упровадження вітчизняними та закордонними підприємствами показали, що основними тенденціями ринку даних послуг є імпортозаміщення, популяризація хмарних рішень, інтеграція Інтернету речей зі смарт- фонами, планшетами, терміналами, зростання попиту на компактні мобільні рішення. За прогнозами фахівців, майбутні автоматизовані системи бізнесу будуть більш інтелектуальні, зі спрощеним та зрозумілішим інтерфейсом, але $з$ розширеними аналітичними можливостями. Таким чином, автоматизовані системи, які пропонує вже сьогодні ринок, стають більш доступними, мобільними, сучаснішими та безпечнішими. Хмарні технології дають змогу використовувати їх навіть невеликими підприємствами як ефективний інструмент управління.

Загалом автоматизувати можна будь-який бізнеспроцес, але завжди необхідно враховувати доцільність таких рішень. У результаті проведеного аналізу вста- 
новлено, що окупність витрат на впровадження, удосконалення та технічну підтримку автоматизованих систем у середньому становить три роки, проте результативність підвищується мінімум на $30-40 \%$.
Подальші дослідження будуть спрямовані на вивчення необхідності й доцільності розроблення та впровадження програмних рішень з автоматизації бізнес-процесів підприємств різних галузей.

\section{Список використаних джерел:}

1. Гандурський А.В. Переваги впровадження IT-систем управління складом на прикладі WMS LOGISTIC VISION SYITE в логістичному комплексі Roshen. ScienceRise. 2015. № 1(16). С. 37-39.

2. Дмитрів К.І., Шпак Ю.Н. Дослідження інформаційних систем в управлінні підприємствами: досвід та перспективи. URL: http://ev.fmm.kpi.ua/article/download/108776/103719 (дата звернення: 17.05.2021).

3. Компанія SAP и её продукт K/3. Advego. URL: http://wm-help.net/lib/b/book/1872605422/4 (дата звернення: 30.04.2021).

4. Ладанюк А.П., Ельперін І.В., Мостенська Т.Л. Оптимізація бізнес-процесів підприємства. Наукові праці УДУХТ. 2002. URL: http://dspace.nuft.edu.ua/bitstream /123456789/4126/1/St_01.pdf (дата звернення: 28.04.2021).

5. Лободзинська Т.П., Черножукова А.М. Порівняльний аналіз автоматизованих систем бухгалтерського обліку на підприємствах України. Ефективна економіка. 2017. № 6.

6. Одарченко Д.М., Соколова С.Б. Модернізація складських приміщень підприємства на базі WMS. Проблеми економіки. 2015. № 4. С. 210-215.

7. Орлова Н.С., Мохова Ю.Л. Впровадження інформаційних технологій у систему корпоративного управління. Вiдкрите освітнє є-середовище сучасного університету. 2017. № 3. С. 355-365.

8. Сокол К.М. Світовий ринок інформаційних технологій у контексті глобалізації світової економіки. Миколаївський наиіональний університет імені В.О. Сухомлинського. 2015. Вип. 3. С. 78-83.

9. Топ 10 ERP- та CRM-систем для України. LiveBusiness. URL: http://www.livebusiness.com.uа (дата звернення: 28.05.2021).

10. Цифровая трансформация MBA IT-Jazz. BAS ERP. URL: https://tqm.com.ua/likbez/article/vnedrenie-bas-erp-zeppelin-ciojazz? (дата звернення: 05.05.2021).

11. The Global Information Technology Report 2016: Innovating in the Digital Economy. World economic Forum. URL: http://www3.weforum.org/docs/GITR2016/WEF_GITR_Full_Report.pdf (дата звернення: 20.05.2021).

\section{References:}

1. Handurs'kyy A.V. (2015). Perevahy vprovadzhennya IT-system upravlinnya skladom na prykladi WMS LOGISTIC VISION SYITE $\mathrm{v}$ lohistychnomu kompleksi Roshen [The advantage of implementing IT warehouse managment systems on the exampe of WSM LOGISTIC VISION SYITE in the logistics complex Roshen]. Scientific Journal "ScienceRise”, vol. 1 (16), pp. 37-39.

2. Dmytriv K.I., Shpak Yu.N. (2002). Doslidzhennya informatsiynykh system v upravlinni pidpryyemstvamy: dosvid ta perspektyvy [Research of information systems in interprise management: experience and prospects]. Available at: http://ev.fmm.kpi.ua/article/ download/108776/103719 (accessed 17 May 2021).

3. Kompaniya SAP ta yiyi produkt K/3. Advego. [SAP and its products K/3. Advego]. Available at: http://wm-help.net/lib/b/ book/1872605422/4 (accessed 30 April 2021).

4. Ladanyuk A.P., Elperine I.V., Mostenskaya T.L. (2002). Optymizatsiya biznes-protsesiv pidpryyemstva. Naukovi pratsi UDUKHT [Optimization of business processes of the enterprise scientific works UDUKHT]. Available at: http://dspace.nuft.edu.ua/ bitstream /123456789/4126/1/St_01.pdf (accessed 28 April 2021)

5. Lobodzynska T.P., Chernozhukova A.M. (2017). Porivnyal'nyy analiz avtomatyzovanykh system bukhhalters'koho obliku na pidpryyemstvakh Ukrayiny [Comperative analysis of automated accounting systems at Ukrainian enterprises]. Efektyvna ekonomika, vol. 6.

6. Odarchenko D.M., Sokolova Ye.B. (2015). Modernizatsiya sklads'kykh prymishchen' pidpryyemstva na bazi WMS [Modernization of warehouses of the enterprise on the basis WMS]. Problemy ekonomiky, vol. 4, pp. 210-215.

7. Orlova N.S. (2017). Vprovadzhennya informatsiynykh tekhnolohiy v systemu korporatyvnoho upravlinnya [Introduction of information technologies into the corporate governance system]. Vidkryte osvitnye E-seredovyshche suchasnoho universytetu, vol. 3, pp. 355-365.

8. Sokol K.M. (2015). Svitovyy rynok informatsiynykh tekhnolohiy v konteksti hlobalizatsiyi svitovoyi ekonomiky [World information technology market in context of globalization of the world economy]. Mykolayivs'kyy national'nyy universytet imeni V.O. Sukhomlyns'koho, vol 3, pp. 78-83.

9. Top 10 ERP- ta CRM- system dlya Ukrayiny [Top 10 ERP- and CRM- system for Ukraine]. LiveBusiness. Available at: http://www.livebusiness.com.ua (accessed 28 May 2021).

10. Tsifrovaya transformatsiya MBA IT-Jazz [Digital transformation MBA IT-Jazz]. BAS ERP. Available at: https://tqm.com.ua/ likbez/article/vnedrenie-bas-erp-zeppelin-cio-jazz? (accessed 05 May 2021).

11. The Global Information Technology Report 2016: Innovating in the Digital Economy. World economic Forum. Available at: http://www3.weforum.org/docs/GITR2016/WEF_GITR_Full_Report.pdf (accessed 20 May 2021).

Chernikova Nataliia

Poltava State Agrarian Academy

\section{ANALYSIS OF SOFTWARE SOLUTIONS FOR AUTOMATING BUSINESS PROCESSES ENTERPRISES}

This research proved the necessity and possibilities of automation of business processes of enterprises in modern business conditions. The article is devoted to the study of software solutions for the automation of business processes and the level of their application by domestic enterprises. The purpose of the article is to analyze such solutions and group them on various grounds for further integration in the practice of enterprises. This analysis confirmed that each 
software solution has its area of use, as well as advantages and disadvantages. The most popular among them are CRM-, ERP-, WMS-, TSM-, BPM-systems, which differ in functionality, cost, the complexity of setup, a set of additional training and technical support services, etc. The experience of the implementation of separate software products at the enterprises is studied. It is established that the advantages of automation are saving resources of the enterprise, reducing the time to perform certain processes, improving the quality of supporting processes and finished products (goods, works, services). The grouping of software solutions by different classification features, namely: by the degree of coverage of business processes, by developers, by functionality, by country of origin, by the number of included modules, by scope, by industry, and others. This classification will simplify the selection of the required software solution that will meet the needs of the customer, to meet certain criteria. The leading companies that offer services for the development, implementation, and maintenance of these programs, as well as their products and competitive advantages, are listed. Approaches to the choice of a technological solution for individual enterprises are proposed. The necessity of automation of as many business processes of enterprises as possible is proved and the existing possibilities for realization of this measure are defined. Based on the results of the research, a conclusion is made about the economic feasibility of implementing automated systems in the activities of enterprises, as well as the direction of further research is determined.

Key words: software products, business processes, automation, analysis and grouping of software solutions, implementation opportunities, competitive advantages.

JEL classification: F20 